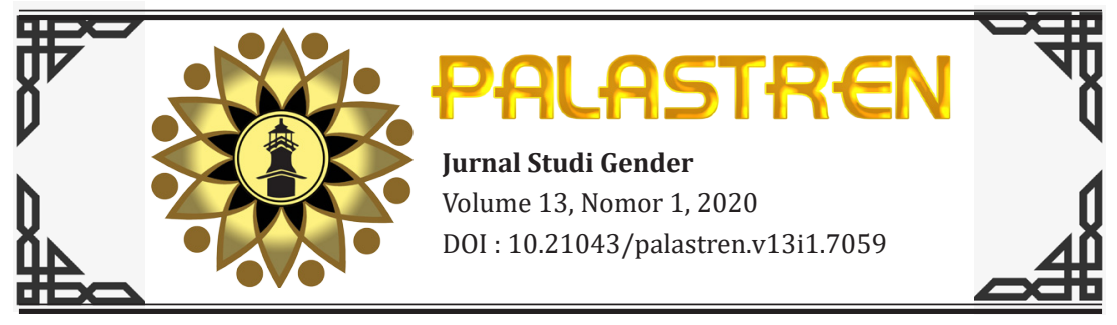

\title{
GENDER BIAS COMMUNICATION AMONG SANTRI IN PESANTREN
}

\author{
Yayah Nurhidayah \\ Eti Nurhayati \\ IAIN Syekh Nurjati Cirebon \\ yayahnurhidayah@syekhnurjati.ac.id \\ etinurhayati@syekhnurjati.ac.id
}

\section{ABSTRACT}

Commonly in the public community, there is a biased pattern of communication between genders, including among the Al-Ishlah santri in Islamic boarding school in Cirebon - West Java. The communication of male and female santri has unique ways. From the beginning, Pesantren offers the different treatment to male and female santri, both in rules, ethics, sanctions, communication, and relationships in general. This study aims to identify several gender biases and stereotypes in various forms of communication between male and female santris in Pesantren. This research used descriptive qualitative methods, data collection techniques using interviews and observations to santris, and data analysis techniques carried out qualitatively in the form of narrative descriptions. The results of the study concluded, there were many gender biases and stereotypes in various forms of communication, such as: communication style, initiative to start a conversation, intensity of conversation 
and interruption, conversation dominance, humor intensity, eye contact, spatial distance, body language, smiling, and touch.

Keywords: Communication; Gender Bias; Pesantren.

\section{ABSTRAK}

Terdapat pola komunikasi yang bias antara perempuan dan laki-laki, termasuk antar santri di pondok pesantren Al-Ishlah Cirebon - Jawa Barat. Komunikasi santri perempuan dan lakilaki memiliki cara unik. Sejak awal, Pesantren menerapkan perlakuan yang berbeda untuk santri perempuan dan laki-laki, baik dalam aturan, etika, sanksi, komunikasi, dan hubungan secara umum. Penelitian ini bertujuan untuk mengidentifikasi beberapa bias gender dan stereotip dalam berbagai bentuk komunikasi antara santri perempuan dan laki-laki di Pesantren. Penelitian ini menggunakan metode deskriptif kualitatif, teknik pengumpulan data menggunakan wawancara dan observasi kepada santri, dan teknik analisis data dilakukan secara kualitatif dalam bentuk deskripsi naratif. Hasil penelitian menyimpulkan, ada banyak bias gender dan stereotip dalam berbagai bentuk komunikasi, seperti: gaya komunikasi, inisiatif untuk memulai percakapan, intensitas percakapan dan interupsi, dominasi percakapan, intensitas humor, kontak mata, jarak spasial, bahasa tubuh, senyuman, dan sentuhan.

Kata Kunci: Komunikasi; Bias Gender; Pesantren.

\section{A. INTRODUCTION}

Verbal and non-verbal communication, is strongly influenced and based on perceptions and ideologies held by the communicator of the communicant. Generally in the community there is a pattern of communication between genders that is biased, including among the Al-Ishlah Islamic Boarding School students in Cirebon - West Java, the meticulous writer who focuses on communication between male and female students. Communication between male and female students in pesantren has unique ways. Pesantren from the beginning gave different 
treatment to make and female, in terms of rules, ethics, sanctions, communication, and relationships in general. In addition, the teaching of books in pesantren generally still uses classical references that contain a lot of gender bias. Therefore, pesantren are often regarded as a source of gender imbalance management, both conceptually and practically. Pesantren often interpreting the Qur' an and al-Hadith are very gender biased, and in practice education still adheres to a patriarchal system and places women in an inferior position.

The main causes of gender bias in boarding schools were alleged by Ema Marhumah (2011) that: (1) Pesantren are generally built, managed, and led by male, namely Kyai or Ustadz as the main role. (2) Female's role is considered not important, sub-odinic, and irrelevant. (3) Islamic boarding schools are considered to have no specific implications for the socio-political life and are detrimental to women, so they are considered to be unimportant to the social life of diversity in a broader context. In addition, the kitabs taught to students are the work of male authors who are very biased and misogynist (Bruinessen, 2012), and many of their teachers are dominated by male, The role of female (Nyai, ustadzah) is only as a complement, usually plays a role in managing consumption, limited treasurer in the field of financial administration, and teaching only to women students.

Incommunicating, essentially someone is negotiating ideas and the meaning of various phenomena, but female's voices are silenced and deemed incompetent, resulting in gaps in communication styles between female and male. Female are educated to always speak politely, slowly and indirectly (to the point), but men are encouraged to speak loudly, decisively, and directly. Female are educated to always show an attitude of love, empathy, and care for others, but male must show a firm, strong, dominant, and independent attitude. Different education, resulting in the distinction of the two sexes. Male are considered more competent and confident to speak in public, but female are considered only competent in speaking in a limited and personal space. 
Male and female typically use different communication styles. These differences are then reinforced by stereotypes in society, thereby affecting perceptions and causing gender differences. Such an assumption is recognized by several experts.

According to Rochefort (in Graddol \& Swann, 2003), male often use strange terms for female, and they understand them, but they are never able to say them. Women have many phrases and words that have never been used by male, but female never use them, because they are afraid of being laughed at and made fun of. The use of language that is typical of men and women was also discovered by Edwar Sapir (in Graddol \& Swann, 2003) in the study of Indian languages in America. According to him, there are several forms of "men language" that are used exclusively by men when speaking to fellow men, and there are several forms of "women language" that are used exclusively for fellow women, and there are languages that are used by men. men when talking to women and there are languages that women use when talking to men. Robin Lakoff (1975) in "Language and Women's Place" explains, men and women communicate using different languages and literally learn different languages because they grow differently. For example, many women are taught passive sentences, many men are taught active sentences. The existence of gender-based language forms implies an awareness that men and women are different categories of humans. The existence of the categories "men language" and "women language" is not based on an awareness that is not underestimated by its speakers. According to Wood (2007), language learned and used in daily by humans reflects and reinforces cultural views and values, including about gender. Language and gender have a close relationship. Language defines, organizes and evaluates gender. Language strengthens social views about sex and gender. Language sometimes demeans and eliminates the existence of women as subjects in conversation. Language can raise awareness, compose perceptions about gender, and offer a mirror of yourself. 
Reality in the community shows, there is an imbalance of communication between men and women due to the existence of views, values, norms, and culture that always places women and men in different positions and sitiations. The results of some study explained, men communication behavior tends to contain: reasoning, logic, power, rank, status, competing, winning, team, and think, while women's communication behavior shows: feeling, empathy, harmony, closeness, relationship, sharing, cooperation, and group.

According to Tannen (2003), sometimes there are obstacles in communication between male and female, even though both speak the same language, because they grow in different cultures. Humans are confined by gender traditions since childhood in conversation, jokes, driving style, leadership style, speaking style, food choices, color choices, and others. Gender ideology is firmly embedded in a variety of actions, beliefs, desires, motivations, and tastes, and is often regarded as reasonable and true. Simone de Beauvoir (1973: 301) in his book The Second Sex states: "one is not born, but rather becomes a woman". The statement explains, people are not born with gender, but must learn behaviors and attitudes that are appropriate to their gender. Becoming a man or woman is a non-stop process that begins before birth. When people imagine whether the baby in the mother's womb is men or women, at first the ritual of walking is not tendentious to a certain sex (it), but after adulthood, will be dubbed as a man (he) or a woman (she ).

The dichotomous characteristics of female and male are constructed from birth. From birth, adults will apply gender practices to their babies and children, treat as a man or woman, and interpret everything that the child does as masculine or feminine. Finally, after going on for years, children will take over what their parents are socializing and apply to the next generation for generations. Wood (2007) states, gender has an influence on verbal and non verbal language. Verbal language includes speech, language and vocabulary. Non-verbal languages include vocal, paralanguage, haptic (touch), kinesthetic (movement, posture 
and gesture), proxemic (spatial behavior). According to Dane Archer (2001) in "Gender and Communication: Male-Female Differences in Language and Non Verbal Behavior", gender gives a strong influence on all aspects of human communication and can bring up very broad social issues. To avoid and minimize interpersonal miscommunication, it is necessary to work to increase knowledge, awareness, and positive attitudes towards people who have different characteristics, gender, culture, and norms of politeness.

In the pesantren environment, female are constructed to have a bargaining position that is lower than male, so that the expression of communication is also different. The practice of gender bias in communication gains legitimacy from the text (kitabs) as a religious doctrine that shapes the behavior of male and female santri and the entire pesantren community, not only gender bias, but also misogyny.

A number of previous studies on male and female communication have been carried out that have inspired and become reasons that reinforce the urgency of conducting this research. The research by Meng Xuemei, Li Jinling \& Wang Binbong (2007) entitled "The Polite Verbal Behavioral in Crossgender Communication" found a dichotomy in communication behavior: (1) Female feel facing obstacles when speaking in public and formal spaces, more considering the conventional needs of the audience, more focused on maintaining relationships, intimacy, and the needs of others, view the conversation as an indication of the relationship, the topic of conversation around yourself, feelings, affiliation with others, home, and family. (2) Male are more passive when talking about private matters, more open in public, formal, and intimate relationships, view public and formal contexts as opportunities to improve their self status and compete, communication styles are referential, conversations are more oriented towards information rather than on social meaning, topics of discussion around competition, sports, aggression, business, and actual issues. Some researchers concluded same findings. Camelia Suleiman \& Daniel O'Connel (2008) wrote an 
article entitled: "Race and Gender in Current American Politics" They found the differences in gender and race affect politicians' speech patterns, which can sometimes be detrimental to them. The use of grammar reflects the existing social order. Male from different classes or genders will show different expressions of attitudes and reactions when dealing with different classes and genders. The research by Cioflica Viorel Mihai (2011) entitled "Gender differences in family communication" shows that there are differences in the communication styles of male and female in family life. Male communication is more oriented toward solving problems, expressing emotions and feelings less, focusing on the content of information rather than emotional affection, and avoiding conflict. Female communicate a lot to give reactions and emotional responses, emphasize intuition, maintain eye contact, express emotions and feelings verbally, provide responses and greater attention to gain appreciation, and have the ability to read nonverbal language and a touch of initiation to maintain intimacy.

Some researcher observed the impact of gender differences in communication on various aspect. Tshilidzi Netshitangani dealt with educational institutions (2008) entitled "Gender differences in communication styles: The impact on the managerial work of a female school principal" found, female leaders can be good communicators who are able to overcome cultural barriers, can practice communication styles that traditionally do not accepted for most female, for example: not using question tags, not making apology, using direct command forms, and doing a lot of interruptions. It shows that differences in communication between men and women are not entirely correct, depending on the context in which the research is conducted, age, social class, awareness of position and role, and personality of the individual itself. The same conclusion was also reached by Daniel McQuiston \& Kathryn A. Morris's (2009) with paper entitled: “Gender differences in communication: Implications for salespeople" They explains, gender differences in communication have implications for business processes. Male and female sellers who use the same grammar, syntax, and vocabulary do not guarantee effective 
communication, because there are several differences in verbal and non-verbal communication styles that have the potential to cause misunderstandings between the two parties. The same research by Charlotte A. Morris (2009) entitled "The Effects of Gender on Communication in the Legal Profession" explains the implication of gender differences. there are differences between male and female in verbal and non-verbal qualities, arguing styles, and ways to influence others. However, the problem of gender effects on communication is not black and white. A person is not destined to succeed or fail because they are female or male. Gender issues are related to the nature and cultural perceptions of female that have long been believed by the community, making it difficult for female to communicate effectively.

Communication style and patterns are concerned by some researches. Jessica McNaughton (2000) wrote "Gender Differences in Parent Child Communication Patterns" found: Parents communicate more openly with girls than with boys. Parents are more protective of girls than boys. Women are more expressive than male and male limit emotional expression throughout adolescence. This shows that gender differences are not influenced by parent-child communication patterns alone, but are influenced by other social factors. Previously, Lynn H. Turner, Kathryn Dindia \& Judy C. Pearson (1995) entitled “An Investigation of female / male verbal behavior in same-sex and mixed-sex conversations" found, female more often use the words justifier, intensifier, and agreement as a compensation for the feelings of female who are powerless, more male use and accept vocalized pauses. This is interpreted, female more often participate in conversations rather than appearing as the main speaker. John Gray (1992) states that the communication styles of male and female are very different, even they are described as being from different planets: male are from Mars, female are from Venus. The finding of Deborah Tannen (1990) differ male and female communication styles. Male are more oriented towards tasks and problem solving, showing status and domination, while female are more oriented towards meeting social emotional 
needs and establishing relationships, showing intimacy, cooperation, and support. In the same result, Nicole A. Sleekier \& Robert Rosenthal (1985) found "Sex differences in non-verbal and verbal communication with Boss, peers and sub-ordinates" concludes, the average female voice is more competent in verbal and non-verbal communication when speaking with boss, while the average male voice is more competent when talking to his peers. Later, Uum Qomariyah (2009) wrote a research entitled "Femininity Accents of Javanese Fishermen Communities on the Rembang Coast" concluded, there were differences in language accents between male and women, and due to social factors and gender construction. Male have a coarse, open, and candid language accent, while female's language accents are ambiguous, speaking remains subtle even in angry situations.

The results of the research above, highlight more on communication in the community in general. This research aims to identify several gender biases and stereotypes in various forms of communication between male and female students in Islamic boarding schools. This research uses descriptive qualitative method, with data collection techniques using interviews and observations to students, and data analysis techniques are done qualitatively in the form of narrative descriptions.

\section{B. DISCUSSION}

\section{The Communication's Style}

Based on observations, there are differences in communication styles between male and female students in Pesantren (Islamic boarding school) Al Islah in Cirebon - West Java. The communication styles of male santri tend to be direct and rude (blunt), the styles of communication of female santri are indirect and more polite. Female when speaking directly are considered impolite, especially in the delivery of messages that contain requests or orders, but male conversations delivered directly are considered by the community to be appropriate and show assertiveness. 
When analyzed from a linguistic approach, the relationship between delivering messages directly (to the point) with politeness, actually does not always have the same implications depending on the context. In the conversational implicature there are several types of conversation, there are special conversations and there are general conversations. In special conversations, the use of implicature is adapted to the context. Language to the point in a conversation is considered impolite if delivered in a relaxed context or atmosphere, and is considered polite if delivered in a serious context or atmosphere. Differences in male communication styles are explained by Charlotte A. Moris (2009), female are more polite and indirect that occur in communication between male and female, and direct conversation usually occurs in communication between female themselves.

\section{The Initiative to Open Communication}

From the observations, the initiative to open conversation in public and formal forums (the participants are a mixture of male and female), is more dominated by male. On the contrary, in an informal forum, it is seen that female have more initiative to open conversation. In the interaction interaction move everyone contributes to the conversation as opening, supporting, and opposing. According to Wood (2007), female's involvement in conversational interactions to maintain relationships, give approval and support, and gain understanding, so female more often take the role of support rather than as opening and opposing conversations of others. It can be seen, every time a female starts a conversation, they always review or acknowledge the conversation from the previous speaker.

Likewise there are differences in responding to conversations. When male are talking, usually female show an attitude of enthusiasm and high appreciation with a nod of the head, say yes ... oh, hmm ..., more often looking at the other person, smiling, and sitting upright facing forward. Male, when female speak only give a minimal response, tend to be indifferent, avoid eye contact, nod their heads, and sit relaxed. Female's 
responses tend to be repeated during the conversation, both at the beginning, middle and end, male generally only respond at the end or after the conversation ends.

\section{The intensity to Do Conversation}

The result of observations show that, in public and formal forums, where participants are a mixture of male and female, male spend more time talking than female. Conversely, in formal and informal forums among female themselves, female are seen actively speaking, can work together to develop ideas, spend hours on long conversations, often overlapping and dominating conversations. According to Leet Pellegrini (in Gradoll \& Swann, 2003), personality factors, emotional states, the social identity of the speaker, the role played by the speakers, and the purpose of the conversation, will influence how the conversation will be arranged and how much each speaker contributes to the conversation. Male talk more than female. Experts talk more than non-experts. The male experts talk more than the female experts.

\section{The Intensity to Do Interruption}

Based on observations, Male interrupt more conversations than female, both male and female speakers, using sentences at length, but men usually do not like to be interrupted, often ignoring interruptions and prefer to continue talking. Women more often interrupt female speakers than interrupt male conversations, use short sentences, and women when interrupted immediately stop the conversation and invite others to talk.

\section{The Domination of Conversation}

Based on observations, male's behavior is filled with competition, such as: struggles, battles, disputes, competitions and struggles. This form of competition is usually manifested in sports activities and rough games. Female prefer to show peace, mediate, and succumb. Even though female have expertise, do 
not use their expertise as strength, but rather try to diminish their abilities. Male, whether they have expertise or not, tend to dominate conversations, whereas what is seen in female such as lack of confidence, is actually only because female are reluctant to appear arrogant, according to the opinion of Tannen (2003): Female are reluctant to show their achievements in public so that they are liked, even if their status is demeaned.

From observations in speech activities (muhadhoroh) at the pesantren, male students are more skilled in giving speeches, are more active, and are more assertive in conveying messages, while women look like memorizing, there is no intonation or appreciation (expression). However, in answering questions raised after the activity, or in providing the essence of all the material that has been submitted, it appears that female are more active in answering questions and are better in giving the essence of all the conversation that has been delivered, while male are more passive, do not want answer the questions asked, and not good at making the essence (conclusion). It can be concluded, male give less attention and respond actively to the conversations of others.

Based on observations in the activities of the santri organization, when giving remarks, male tend to use the word "I" more, while female more often use the word "we or us". The use of the word reference reflects gender differences in communication. The reference word " $\mathrm{I}$ " is perceived as someone who has high self confidence, independent, and has power. The word "we or us" refers to the speaker representing himself and others (community). That was interpreted as being dependent, not confident, and sub-odinate.

\section{The Intensity of Humor}

Based on the observation, female when they were in the female fellow community they many catapult humor and very little catapult humor to the group of a mixture of male and female, according to the opinion Michel (in Tanen, 2003), female 
less talking and do humour in arenas public and people who do not familiar ( foreign ).

\section{The Eye's Contact}

Observations show, male are less fond of eye contact than female. This seems to be related to the communication characteristics of male who want to always show dominance, power, and status. Direct eye contact is an emotional sign. Typically, a person tends to make direct eye contact to people he likes, and few to make direct eye contact to someone he doesn't like.

However, eye contact in the communication of male and female students is controlled by the rules and teachings they receive at the pesantren. Relations between male and female, not only in eye contact, but in interacting widely are very limited. Female just maintain their views on the opposite sex who are not muhrim, must not touch, are prohibited from meeting and communicating with each other, except in forums that have been determined by the pesantren and within the limits of supervision.

\section{The Spatial Distance}

From observations on the male and female students's way to take position or distance in attending the recitation, it can be concluded that male are very easy to form a line and are less comfortable sitting close together, while female look difficult to make a line, prefer sitting in a group, even when Kyai order female students to sit forward to the front row, they invite each other, usually it is the one who comes back who must advance to the front row, and even then very forced.

However, spatial distance in communication between male and female is very limited and determined by the rules made by the pesantren. Male and female should not be in direct contact; Male and female should not look directly at one another; Male and female should not touch. 


\section{The Body Language}

The observations show, women move more (attractively) than male, when communicating with male. Conversely, when communicating with fellow female, their attractive behavior tends to decrease. This is according to Burgoon et. all. (in Wood, 2007), female's facial expressions and body movements are generally signals that they can be approached, friendly, and simple. In stereotypical views, facial expressions and gestures are considered feminine because they show they are protected and controlled, so that male do not or little do it.

\section{Smile}

From observations, female generally smile more than male, even when the situation does not require smiling. The female's motives of smiling are not always related to situational demands as they are to male. Likewise, female's smiles are not entirely consistent with messages conveyed through verbal channels or tone of voice. Smiles for female show intimacy, friendliness, courtesy, relationships, influence and support. Male smile a little, because they tend to be serious and task oriented. Female also smile more often when there are people who ask her to smile. Unlike male, they smile a little, reluctant to return a smile, unless the person is truly known and liked.

Smiling is seen as part of the feminine role and as something that must be done by female rather than merely showing happiness or friendship. Female will smile, even if they are not in a happy condition. Conversely, male smile only when happy. People who have dominant (high) status tend to smile less and people who have sub-ordinate (low) status tend to smile more. But according to observations, a smile is not always related to one's status, but more related to female's gender, because female are socialized to always smile and look pleasant. 


\section{Touches}

Based on observations, male and female touch differently. The difference in the meaning of touch can be a cause of miscommunication between the two. A touch for women expressing support, affection, comfort. The touch of a male confirms power and expresses sexual interest. Female never interpret the touch of male as a sexual invitation, but male often interpret the touch of female as a sexual invitation.

In the pesantren environment, male and women should not be in contact with non-muhrim. Therefore it is forbidden to shake hands with men. In eastern cultures, female in contact with male within the limits of politeness are still tolerated, such as shaking hands, touches that express intimacy, affection, and support. However, touch between male and male rarely occurs because it is considered impolite, except in family relations. Thus according to Wood (2007), touch behavior reflects social norms and imposed limits.

Based on the research findings, gender biases and stereotypes are found almost in all forms of santri communication in pesantren. But this is often considered natural and is not a crucial problem that needs change. According to Tannen (2003), no one can deny that male are the dominant class in society, and many male try to control female. In today's global era, female can empower themselves to be competent and seen as competent, both in speaking, behaving, acting and behaving without losing their identity.

\section{CONCLUSION}

Based on the results of the research and discussion above, it can be concluded that there are many gender biases and stereotypes in almost all forms of communication between male and female students in Islamic boarding schools, especially in terms of: initiative style of initiating conversation, intensity of conversation, intensity of interruption, dominance in conversation, intensity of making humor, eye contact, spatial distance, body language, smile, and touch. 
These reality is already a common phenomenon in the community, which does not only occur in pesantren which are the object of research, but is still not seen as a crucial problem that needs to change, because the community itself lacks adequate gender awareness, even some parties feel benefited from the condition of the gap mentioned, as the status quo of condition in the community. 


\section{REFERENCES}

Archer, D, 2000, Gender and Communication:Male-Female Differences in Language and Non Verbal Behavior. Retrieved from http//www.berkeleymedia.com

Bruinessen, M. Van, 1994,Kitab Kuning: Pesantren dan Tarekat. Bandung: Mizan.

Cox, C. A. (n.d.), Differences in Verbal Gender Communication. Retrieved from http://www.ehow.com/ list_6139416differences-verbal-gender communication. html\#ixzz1kzelD0p4.

Graddol, D, \& Swann, J, 2003,Gender Voices. Pasuruan: Pedati.

Gray, J, 2003,Men are from Mars, Women are from Venus: The Classic Guide to Understanding the Opposite Sex. USA: Harper Collins Publisher. Inc.

Lakoff, R, 1975, Language and Woman's Place. New York: Harper \& Row.

Marhumah, E, 2009,Gender dalam Lingkungan Sosial Pesantren: Studi tentang Peran Kyai dan Nyai Dalam Sosialisasi Gender di Pesantren al-Munawwir Krapyak Yogyakarta. UIN Sunan Kalijaga Yogyakarta.

Mc.Quiston, D., \& Morris, K. A, 2009, Gender Differences in Communication: Implications for Salespeople. Journal of Selling \& Major Account Management: 54.

Mihai, C. V, 2011, Gender Differences in Family Communication. Retrieved from http://www.doctorat.ubbcloj.ro/ sustinerea-publica/rezumate/2011.

Mintorogo, J. M., Adib, A., Wijayanti, A., \& Petra, U. K. (n.d.). Perancangan Media Interaktif Pengenalan Alphabet Berbasis Alat Permainan Edukatif untuk Anak Usia 2-4 Tahun.

Netshitangani, T, 2008, Gender Differences in communication styles: The impact on the managerial work of a woman school principal. Proceeding. Retrieved from http:// anzca08.massey.ac.nz. 
Qomariyah, U, 2009, Aksen Femininitas Masyarakat Nelayan Jawa di Pesisir Rembang. Jurnal Lingua, v(2).

Sleekier, N. A., \& Rosenthal, R, 1985, Sex Differences in Nonverbal and Verbal Communication With Bosses, Peers, and Subordinates. Journal of Applied Psychology., 7(1).

Suleiman, C., \& O'Connel, D, 2008, Race and Gender in Current American Politics. Journal of Psycholinguist, (6), 37.

Tannen, D, 1990,You just do'not Understand. New York: Ballatine Books.

Tannen, D, 1994,Gender and Discourse. New York: New Oxford University.

Turner, Lynn, H., Dindia, K., \& Pearson, J. C, 1995, An Investigation of female/male verbal behaviors in samesex and mixed-sex conversations.

Wood, J. T, 1997,Communication Theories in Action: An Introduction. Bellmont: Wadsworth.

Wood, J. T, 2007,Gender Lives: Communication, Gender, and Culture. USA: Wadsworth Cengage Learning.

Xuemei, M., Jinling, L., \& Binbong, W, 2007, The Polite Verbal Behavioral in Cross-gender Communication. Intercultural Communication Studies, XVI(2), 192. 